\title{
VILNO AGAINST MOSCOW
}

\author{
Рец. на кн.: Янушкевич А. Н. Ливонская война. Вильно против \\ Москвы: 1558-1570. - М. : Квадрига : Русская панорама, 2013. - 384 с. \\ Review of: Janushkevich, A. N. (2013). Livonskaja voina. Vilno pro- \\ tiv Moskvy: 1558-1570 [Vilno against Moscow: 1558-1570]. 384 p. M.: \\ Kvadriga; Russkaja panorama.
}

In their review of a monograph by A. N. Janushkevich, The Livonian War. Wilno against Moscow: 1558-1570. (Moscow: Kvadriga; Russkaya Panorama, 2013) the author points out that the monograph is a profound study, critically reviewing the preceding research of the military history of the $16^{\text {th }}$ century. The review also analyzes the historical sources of the book as to their completeness and the degree of representativeness, looks into the arguments put forward by the author consecutively considering each chapter, and reveals the innovative conclusions, as well as comments on a number of doubtful statements made by the author.

Keywords: A. N. Yanushkevich; Livonian War; military history of the $16^{\text {th }}$ century; Polish-Lithuanian Commonwealth; Stephen Báthory.

В представленной рецензии на книгу А. Н. Янушкевича «Ливонская война. Вильно против Москвы: 1558-1570» (М. : Квадрига : Русская панорама, 2013) резюмируется, что книга производит впечатление серьезного нового исследования, критически суммирующего предыдущие наблюдения по военной истории XVI в. Анализируется полнота и репрезентативность исторических источников монографии, последовательно по главам приводятся аргументы автора, выявляются новаторские выводы и вместе с тем показывается сомнительность отдельных положений автора.

Ключевы е слов а: А. Н. Янушкевич; Ливонская война; военная история XVI в.; Речь Посполитая; Стефан Баторий.

A researcher of the Central European late Medieval and Early Modern war history has certain advantages as compared to the scholar of Medieval Russian war history. The former has access not only to comparatively detailed written accounts of wars, but also to much better preserved 
collections of documents on the history of military organization, fiscal systems, and representative establishments. In this book, the author, A. N. Janushkevich, makes full use of these advantages.

To reconstruct the confrontation between Lithuania and the Russian state - a conflict of destiny-changing proportions for the former the author draws upon an exhaustive number of archival and published sources. A. N. Janushkevich demonstrates a rather liberal attitude to Russian historiography; in particular, he convincingly takes A. L. Khoroshkevich to task for uncritically following A. A. Zimin. The latter, clearly, believed control of the principality of Staritsky to be the main aim of the oprichnina terror; he even linked a visit by the Tsar to the town of Staritsa in spring 1563 to Ivan the Terrible's struggle with the 'Boyar opposition' (p. 80). Janushkevich also disagrees with Khoroshkevich's assessment of the Peace Treaty of June 1570, arguing that Russia had clearly won the confrontation, having retained a sizeable part of Livonia and Polotchina (p. 127).

In the first chapter Janushkevich analyzes the course of military operations and the diplomatic relations between Lithuania and Russia in the period between 1558 and 1570. He makes a significant contribution to the understanding of this already well-researched issue. Thus, his assertion that the Russian government was poorly informed about the situation in the Baltic States in 1557 makes perfect sense. It is well known that in the late summer and early autumn of 1557, a war took place between Lithuania and the Livonian Order. It ended with the signing of the Pozvolsk Treaty on $14^{\text {th }}$ September 1557 . According to the terms of the Treaty, Gotthard Kettler, a protégé of the Polish King Sigismund II Augustus, became the Master of the Order. At the same time, the issue of the treaty signed with Lithuania was not even raised during Russia's negotiations with the Order, and Janushkevich justly concludes that the Moscow diplomats were ignorant of this important political event (p. 32).

The author is objective in his analysis of the reasons for Lithuania's defeat, particularly, the loss of Polotsk. The weak capability for mobilization in Lithuania is well visible during the comparison of the tempo of the draft in the two armies: while the Russian army was mobilized over a short period of time and by December 1562 had 31,000 warriors in its fighting units alone, by the end of December, the Lithuanian army, which began drafting on December $6^{\text {th }}$, numbered no more than 100 men (p. 70). Janushkevich justly acknowledges the uttermost importance of the Battle of Ula. Between this battle and the mid- $17^{\text {th }}$ century, Russia made no attempt to penetrate the territory of Rzeczpospolita and avoided all field conflict (p. 99). The author complements Russia's significant investment in constructing castles on occupied Lithuanian territory - namely, the Ula castle where a large garrison with a huge amount of artillery was stationed (p. 118).

In the second chapter, the author concentrates on the organization of the military forces of the Grand Duchy of Lithuania. Janushkevich clearly shows that up until the Sejm of May 1563, the Lithuanian authorities were not capable of organizing effective resistance to Russia’s advance because 
of the weakness and indiscipline that characterized the process of Rzeczpospolita mobilization (p. 138-139). However, the decisions of the conventio generalis (the People's Sejm) in May and June 1563 represent a successful attempt to adapt the archaic community of the Grand Duchy to the needs of a large-scale war. In particular, it was decided to provide one drab (infantryman) for every 20 voloks (land divisions). Another noteworthy innovation was a draft of artisans, putnye (administrative), boyars and peasants with carts and $y$-shaped bear spears, much like the draft of the pososhnaya militia in Russia (p. 142-143, 146).

The first results of the work undertaken by the Grand Duke's chancellery and the Sejm were not impressive: according to the registry of 1565, Rzeczpospolita mobilization collected a mere 6594 horse warriors by October of that year. However, by the autumn of 1567, Rzeczpospolita mobilization had succeeded in assembling more than 27 thousand cavalry and infantry, a figure comparable to the strength of the Russian army during the Polotsk campaign, described above (p. 149-150, 161). An analysis of the structure of mercenary units in the Lithuanian army lead the author to a convincing conclusion about the difference between the Cossack fighters mentioned in the $16^{\text {th }}$ century documents, and the later existing units of the actual Cossacks (p. 177).

The author provides data about the decision of the Gorodensky Sejm in 1566/67, according to which an additional levy for the draft of ten thousand soldiers had been administered (p. 183-184). According to the author, the Poles lost the opportunity of drafting 3,500 mercenary soldiers who had previously taken part in two successful military campaigns: one the battle in Nevel in 1562, and another, a raid into the Pskov territory in March 1565 (p. 202-205).

The sources upon which the second chapter of Janushkevich's work is based, give an idea about the resources at the disposal of the Grand Duchy of Lithuania. The third chapter, in turn, contains excellent material on the state finances, for which Russian historians have no comparative figures. The research masterfully shows the differences between the financial systems of the Grand Duchy of Lithuania and Russia. Lithuania's skarb (the State Treasury) had been supplied by special taxes, destined for war (such as serebshchina and pogolovshchina), only by direct resolutions taken by the Sejms. For the collection of serebshchina from the masters' estates, a direct ruling of the Great Duke was required (p. 217). Sometimes, as in 1568 , the rate of serebshchina was raised by $60 \%$ as compared to the previous year (p. 230). The estates of the Catholic and Orthodox clergy were also taxed and had to provide soldiers; moreover, the Polish gentry at the Sejms demanded the clergy be stripped of half of their churches' possessions (p. 35).

The commoners, the Jews and the magnates were designated groups for funding the war. The first two groups were forced into making special loans (pozychki), similar to the 'requested money' (zaprosnye den'gi) used in $17^{\text {th }}$-century Russia. Similarly to the case with the 'requested money', the Lithuanian government promised to return pozychki from the tax 
revenue, i. e. to count them against future taxes. However, as the author shows, already in 1565 pozychka was not considered as a loan and was not supposed to be returned. One significant difference from the situation in the fiscal sphere in Russia, however, was the weakness of the state apparatus; in 1567 the Great Duke's treasury consigned a guarantee for the repayment of the loan, but in the case of any shortfalls it threatened the cities by allowing mercenaries to collect the missing money independently (p. 236-237).

The Jewish communities of the Grand Duchy were in possession of sizeable financial resources, and therefore served as an inexhaustible source of revenue. The collection of pozychki from the Jews was successful due to the possibility of rapid mobilization: thus, in 1567 the special tax collected had to be transferred to the treasury a mere week after the issue of the taxation decree (p. 244).

A. N. Janushkevich has successfully reconstructed the budget of the Grand Duchy of Lithuania in 1561-1566. An abrupt diminishing in the treasury's revenue between 1564 and 1566 demonstrates strains in the state economy of Lithuania and the powerlessness of its fiscal apparatus (p. 246-247). In these circumstances, the ruling elite of the Duchy levied itself with a part of the expenses needed for the maintenance of its mercenary army. The author provides impressive data on the expenses of the Orsha head F. Kmita, Field Hetman R. Sangushko, and voivode A. Polubenskiy. These examples clearly show the vulnerability of the administrative and political systems of the Duchy, because the maintenance of the mercenary units was a sort of levy in exchange for feasible privileges: the magnates received the right of lifelong taxing of the towns and the voitovstvos (the boyars settlements) (p. 255, 273).

The fourth chapter of the book is dedicated to the study of the sociopolitical changes in the state system of the Grand Duchy of Lithuania caused by war. The author correctly interprets the reasons for the issuing of the Vilno Privilege on $8^{\text {th }}$ June 1563, when Christians of all confessions were granted equal rights. In his opinion, the main reason for the issue was the desire to consolidate the Orthodox gentry of the Eastern lands of the Grand Duchy in the event of the advance of the Russian armies under the banner of 'protection' of the Orthodox Church from the Catholics (p. 278-280).

Regarding the important question of the nature of the political struggle in the Sejms in the 1560s, the author supports the view of I. I. Lappo, who, unlike M. K. Liubavskii, believed that between the magnates and the gentry of the Duchy there were no fundamental disagreements about union with Poland. The magnates supported the gentry in their quest to introduce the 'nobility democracy' by creating a common Polish-Lithuanian Sejm and preserving the local Sejms.

At the same time, the author recognizes the special position occupied by the group of Radziwiłł magnates who favored the preservation of the sovereignty of Lithuania (p. 296, 307). Janushkevich rightly points to the formal nature of the 'nobility democracy', under the guise of which the magnates' clientele was effectively functioning, and the young nobles moved to private service in the courts of those magnates (p. 304). 
Describing the situation of the population in Northern Belorussia living on the frontline, the author outlines the common practice of survival when, regardless of religion or ethnic kinship, local residents supported the side that seemed the strongest at any given moment (p. 326-339).

The author's conclusions, on the medieval character of the Rzeczpospolita military drafts, that eventually had to be replaced by the mercenary units, also prove valid (p. 341). The limited resources of the Great Duchy of Lithuania did not allow for the substitution of the military drafts by the mercenary army; it was only after the election of Stefan Batory as King of the united Rzeczpospolita that he managed to hire a significantly large military contingent in Germany and Hungary and to turn the tide of the war. A map of the military campaigns in Northern Belorussia, drawn by V. N. Temushev, deserves particular mention. All of the above proves the significant scientific value of the research conducted by Janushkevich.

On the other hand, not all of the interpretations and conclusions presented by the author are indisputable. For example, the author believes that taking possession of Polotsk did not bring Russia any tangible strategic advantage, because the Polotsk land formed a 'wedge' between Vitebsk and the Lithuanian possessions on the lower Dvina river (p. 64). However, one should keep in mind two things: first, that the $16^{\text {th }}$ century maps did not render space adequately; and second, that the Russian command had planned to conquer Vitebsk after Polotsk - this was the aim of the 1564 winter campaign. The defeat of P. Shuiskiy's army near Chashniki spelled the end of those plans; however, in the case of success, the takeover of Polotsk would have been undeniably justified.

Chapter One, with all its richness, is mainly concentrated on the description of the war in Northern Belorussia, often ignoring the situation in the Baltic countries. For instance, the exceptionally important act of the stripping of Livonia of its inner political autonomy, and its inclusion into the Great Duchy of Lithuania, is mentioned only momentarily, in a fragment devoted to the Treaty of 1561 (p. 56). Yet, this fact calls for a different understanding of the creation of the Duchy of Magnus in Livonia by Ivan IV in 1570 - it was clearly intended to fill the resultant political vacuum. Similarly, it is difficult to accept the generally dismissive tone towards the enemy of Lithuania - the Russian state, repeatedly described as backward and barbaric. Firstly, in accordance with the traditions of Anglo-American, Polish and Lithuanian historiography that considers the Lithuanian-Russian state as Lithuania, Russia in the monograph is often referred to as 'Muscovy'. Despite the fact that we have previously written about this inconsistency on several occasions, it is still necessary to repeat the point: if in the naming of the monarchical state one takes into consideration the titles of the monarch, then the country, led by 'The Tsar, the Monarch and the Grand Duke of All the Russias' should certainly be referred to as the Russian state, and not simply 'Muscovy'.

Secondly, the author does not include important and historiographically well-known facts concerning the reorganization of the state apparatus 
and the military system of Russia in the 1550s. It was due to the reform of the so-called 'Elected Rada' that the reform of the cadastre system (soshnoe pis'mo) and the land reform were undertaken in Russia, resulting in the increase of tax revenues to the treasury; "Prigovor o kormleniyakh $i$ sluzhbe" ('The Tsar's Decree on Maintenance and Service', 1556), in turn, endorsed the increase in numbers and the re-equipping of the cavalry. These facts support Dunning's contention that in the middle of the $16^{\text {th }}$ century, the Russian State, along with the Kingdom of Castile, was one of the first fiscal-military states in Europe [Dunning].

Despite these reservations, this book by A. N. Janushkevich should be recognized as a very important study, organically complementing, and in terms of its volume and the originality of its sources used even surpassing, Russian historians' works, which are based mainly on Russian sources on the history of the Livonian War.

Dunning, Ch. (2014). Were Muscovy and Castile the First Fiscal-Military States? Quaestio Rossica, 1, 191-197.

The review was submitted on 24.05.2014

\author{
Владимир Анатольевич \\ Аракчеев \\ профессор \\ Россия, Екатеринбург \\ Уральский федеральный \\ университет \\ arakk@rambler.ru
}

\author{
Vladimir Arakcheev \\ Professor \\ Russia, Yekaterinburg \\ Ural Federal University \\ arakk@rambler.ru
}

